\title{
DESIGNING ALGORITHMS FOR SERVICE ROBOTS ON THE BASIS OF MIVAR APPROACH
}

\section{Panferov A.A., Zhdanovich E.A., Yufimychev K.A., Chuvikov D.A.}

Opportunities of mivar-based approach for robots have been analyzed. Mivar-based method of rapid logical inference for calculating random algorithms of service robot functioning has been tested successfully. The logical model of office robot-guide functioning with the application of mivar-based method of rapid logical inference in the software environment "KESMI" (Wi!Mi 1.1) has been developed. Formalized map of the office for service robot has been described in mivar matrix, 63 objects for 100 rules. Simulation of robot functioning in the software environment V-REP has been performed.

Keywords: algorithm calculation; artificial intelligence; MIVAR; service robotics; robot; simulation modeling.

\section{Introduction}

The International Federation of Robotics (IFR) divides all the robots into industrial robots and service robots [1].

Industrial robots are automatically controlled, reprogrammable, multipurpose manipulators, which may be either fixed in place or mobile for use in industrial automation applications [1]. Industrial robots are designed to operate in a strictly controlled environment carrying out a limited set of production tasks. At the stage of implementation a highly limited set of specific algorithms and perception models of the outside world is required to ensure proper operation of industrial robots. It is important that such robots are capable of operating only within their algorithms and models. 
Service robots are defined as mobile autonomous programmable or trained robots designed to operate in uncontrolled environment as well as interact with human. The autonomy of service robots is regarded as their capability to perform set tasks fully autonomously without involvement of an operator. Currently, capabilities of modern service robots are limited. Robots have not achieved reflex level of animals, whereas it is necessary to develop the level of 'a reasonable man'. Nowadays, new mivar-based technologies have made considerable advances in this area.

\section{Analysis of mivar-based technology capabilities for robots}

Mivar-based technologies have combined and integrated evolutionary databases with logical-and-computational processing with the linear complexity of logical inference [2-30]. Mivar-based technologies of information accumulation and information processing, which have been developing in Russia since 1985, have allowed us to create logical artificial intelligence or in other words 'brains' for robots [23]. For example, it is obvious that mivar-based technologies of information accumulation allow us to develop evolutionary models for real life with extremely large amounts of data. To ensure text meaning understanding the graph consisting of 160000 nodes and more than 600 000 arcs has been designed in mivar-oriented information space [30].

From the perspective of robotics, it is important to underline mivar synthesis of models and methods for online diagnostics [17], which allowed us to justify the possibility of developing control system for autonomous mobile robot teams in 2004 [18]. Since 2012 mivars have allowed us to generalize logic in the field of AI and solve tasks of natural Russian language understanding [19], taking into account results of mivar intelligent system development [20], active reflection theory [21], evolutionary knowledge bases [22]. Modelling processes of text meaning understanding, speech and image understanding [23] has allowed us to use the results of logical and computational information processing for real-time simulators [24]. Research of mi- 
vars on multi-processor computational cluster was carried out in 2009 [25] and the UDAV software was developed [26]. In the process of modelling text meaning understanding, speech and image understanding by computers [27] the automatic image tagging system based on mivar-based technologies has been developed [28] and the analysis of technologies of three-dimensional modelling and 3D object development has been carried out [29]. Thus, efficiency of mivar expert system application to solving tasks of text understanding and image recognition has been proved [31].

It should be noted that there is the expert system designer KESMI (Wi!Mi 1.1), which is a convenient tool for designing decision support system (DSS) for robot. Moreover, research has been carried out [810], which demonstrated the prospect of combining mivar logical kernel and simulation modelling systems [7]. Such synthesis will enable us to model behavior of industrial robots, which will allow us to test DSS algorithms in different set conditions.

Consequently, all the necessary conditions for development of autonomous intelligent robot with mivar 'logical brains' currently exist in Russia.

\section{Research levels of intelligent robots and service robots}

From the perspective of system approach, it is important to note that development of autonomous intelligent robots involves many problems, which can be divided into the following information processing levels:

1) reflex level - the capability of a robot to perform its main functions analogous to functions of animals (to stand, move, run, see obstacles etc.);

2) logical level ("level ME") - the capability of a robot to understand cause-effect connections or if-then relationships on the logical level and solve intelligent tasks analogous to functions of a single human;

3) social level - ("level "WE") - the capability of a robot to interact with a multi-robot team and make joint decisions considering the impact of the environment and other possibly hostile multi-robot teams, mechanisms and people. 
Service robots should have the following properties:

1. Service robots should be mobile and autonomous;

2. Service robots should be capable of operating in dynamically changing environment that is difficult to forecast;

3. Service robots should be capable of performing different tasks, adopting and training.

4. Service robots should be capable of interacting or communicating with a human;

5. Service robots should be capable of functioning in heterogeneous teams where functions can be distributed between robots depending on situation.

\section{Problems of service robot control}

As a rule, service robot algorithms are long and complicated network of rules written separately for different environmental conditions. The number of possible variants of algorithms in service robot's library is limited due to the necessity of formalizing them manually and can reach 5000 for modern control systems. However, such a large number of predefined algorithms do not exhaust all possible situations in which a service robot has to make decisions.

According to their goals and properties, service robots require a flexible system of synthesizing algorithms to solve tasks in unpredictable situations. A required robot action algorithm should be calculated anew each time, when robot failed to find a suitable variant in its library of predefined algorithms in the process of solving task in certain environment.

Therefore, one of the major problems of service robot control is the task of calculating robot action algorithms from the set of possible commands in real time.

Theoretical basis of proposed solution to the problem of service robot control uses mivar-based approach to developing artificial intelligence. This is a new modern approach to developing intelligent systems and algorithms [2-30], which has been developing in Russia 
since 1985 . Whereas traditional approaches to information processing separate storage in databases, logical inference and computational processing, mivar-based approach allows us to design multidimensional and evolutionary systems processing information in real time and combining logical inferences with computational processing. The basis of multidimensional evolutionary mivar-based approach is representation of the real world description in the form of three-dimensional space, the axes of which are concepts: object, property, relation (VSO) [2-30].

Due to mivar-based method of rapid logical inference it is possible to calculate optimal robot operation algorithms depending on environmental conditions, which ensures that robot makes rational and optimal decisions [2-30].

\section{Practical application of mivars \\ to motion control of a service robot}

Let us consider the problem of ensuring service robot motion in the office. The robot-secretary is designed to guide visitors through the building. For example, a job applicant came to the office and it is necessary to guide him to the interviewer.

The robot can perform the following elementary actions: moving forward, backward, turning to the left, to the right. Mivar motion control model integrates elementary actions into four commands:

- Move_left - movement to the left;

- Move_right - movement to the right;

- Move_down-movement down;

- Move_up - movement up.

There is map of the office in the robot's memory. In the map the space is divided into discrete areas corresponding to geometrical dimension of the robot. Then according to this geometrical model the graph is built, where connections between discrete areas corresponds to authorized movements of the robot (forward, left, wright, backward), if motion between discrete areas is forbidden, there is no 
connection. A rule is represented in Fig. 1, which demonstrates the possibility of transition between discrete areas and direction of this transition. This structure is a basic element, from which the model of the office is constructed.

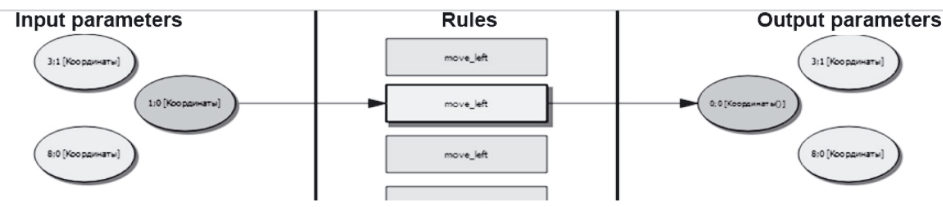

Fig. 1. An example of bipartite movement graph

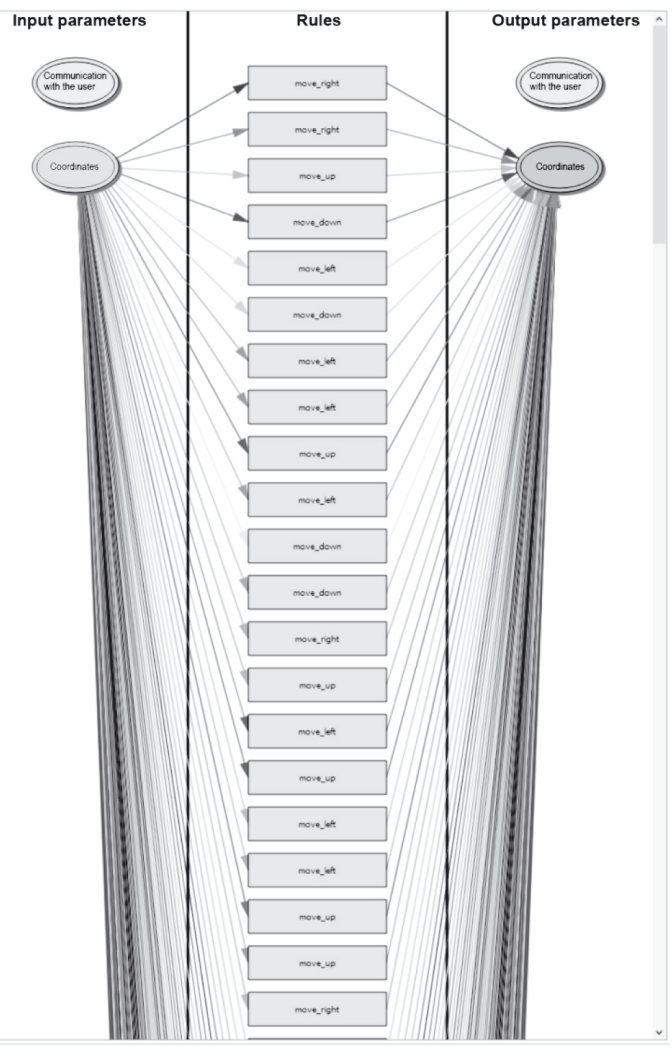

Fig. 2. Bibartite graph of robot motion 
The form of the model is represented in Figure 2, the number of rules is 100, the number of parameters is 63 (discrete areas are regarded as parameters).

To design robot motion algorithm the mivar-based method of rapid logical inference is used. Using this method it is possible to construct sequences of elementary robot movements designed to move from random points in the building to the required ones. There is an opportunity to reconsrtuct the motion algorithm when obstacles occur in the path of the robot.

Modelling of mivar motion control model in the V-REP environment has been implemented (Fig. 3).

Table 1 shows the correspondence of desks and coordiantes of the mivar model.

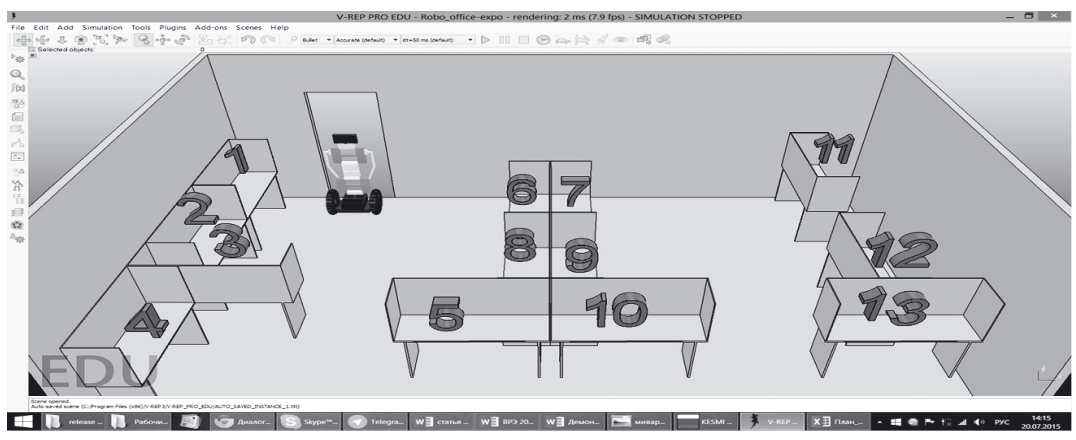

Fig. 3. The robot is at the entance of the room

Table 1.

The correspondence of desks and coordiantes of the mivar model

\begin{tabular}{|c|c|c|c|c|c|c|c|c|c|c|}
\hline & & \multicolumn{9}{|c|}{$\mathrm{X}$ coordinates } \\
\hline \multirow{8}{*}{ 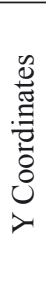 } & & 0 & 1 & 2 & 3 & 4 & 5 & 6 & 7 & 8 \\
\hline & 0 & 1 & & & & & & & & \\
\hline & 1 & & & & & & & & & \\
\hline & 2 & 2 & & 6 & & & 7 & & & 11 \\
\hline & 3 & 3 & & & & & & & 12 & \\
\hline & 4 & & & 8 & & & 9 & & & \\
\hline & 5 & & & & & & & & & \\
\hline & 6 & 4 & & 5 & & & 10 & & 13 & \\
\hline
\end{tabular}


It is necessary to obtain service robot motion algorithm in the environment KESMI (Wi!Mi 1.1). To do this it is necessary to click on the checkbox with coordinates $(5 ; 6)$ that corresponds to the desk No.9 (Fig. 4).

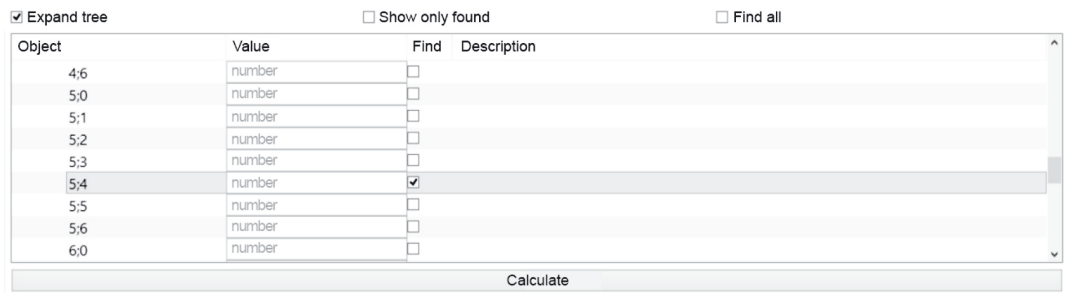

Fig. 4. The tab «Smart calculator»

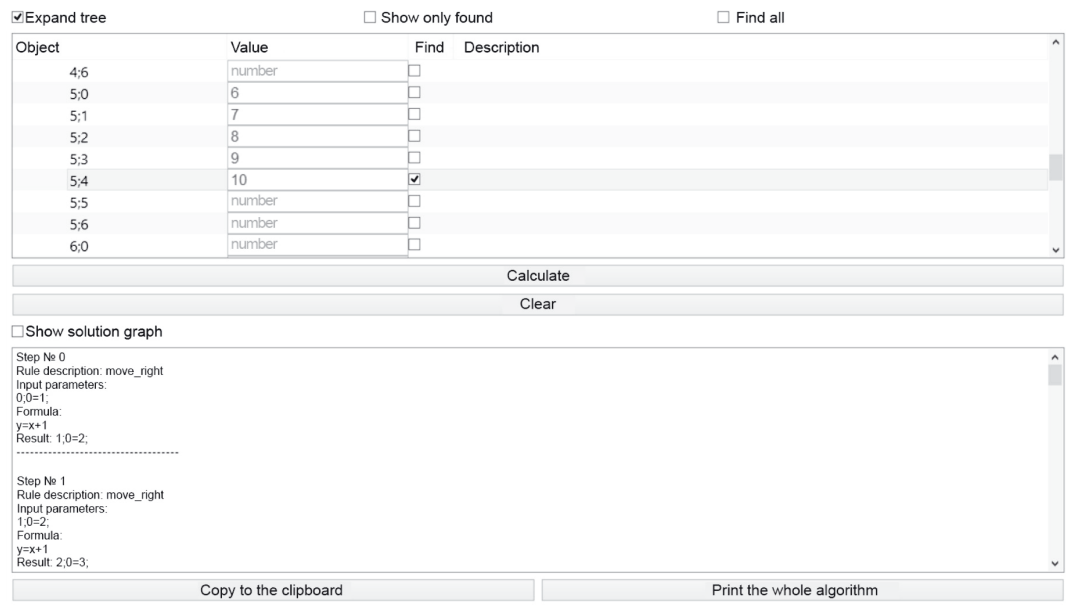

Fig. 5. The calculation of motion algorithm in the KESMI environment

Then the obtained algorithm for motion from the entrance of the room to the desk No.9 is represented (Fig. 6):

Step № 0: move_right

Step № 1: move_right

Step № 2: move_right

Step № 3: move_right 
Step № 4: move_right

Step № 5: move_down

Step № 6: move_down

Step № 7: move_down

Шаг № 8: move_down

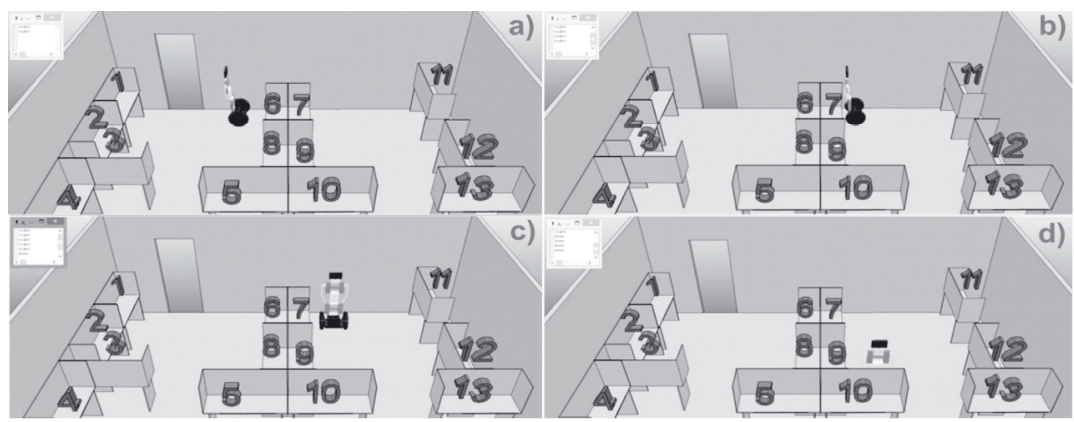

Fig. 6. The application of the algorithm in the V-REP environment: a) - step No.0 is implemented: move_right; b) - step No.4 is implemented: move_right; c) - step No.5 is implemented: move_down; d) - step No.8 is implemented: move_down

\section{Conclusion}

Thus, mivars have developed a new tool, which opens up entirely new opportunities for intelligent robotics.

Manual formalization of all possible robot operation algorithms used for industrial robots can not be applied to service robots due to a large number of robot action algorithms depending on the set task and environment.

Mivar-based approach to developing artificial intelligence and mivar-based method of rapid logical inference allows us to calculate optimal algorithms taking into account the impact of the environment.

The calculation of algorithm in the KESMI (Wi!Mi 1.1) environment is carried out rapidly with the linear complexity, which soves several important problems of modern robotics:

- accelerating the calculation of robot reaction algorithm in real-time; 
- the possibility of applying less powerful and, consequently, energy-efficient and cheap calculators (without loss of calculation speed).

\section{References}

1. IFR International Federation of Robotics, available at: http://www.ifr. org/

2. Varlamov O.O. (2002), Evolutionary databases and knowledge bases for adaptive synthesis of intelligent systems. Mivar-oriented information space. [Evolyucionnye bazy dannyh i znanij dlya adaptivnogo sinteza intellektual'nyh sistem. Mivarnoe informacionnoe prostranstvo], Radio and communications, Moscow, $288 \mathrm{p}$.

3. Varlamov O.O. Logical artificial intelligence has been developed on the basis of mivar approach! MIVAR: active databases with linear logical inference $>3$ million rules $=>$ meaning understanding + singularity in virtual reality. Saarbrucken, Germany: LAP LAMBERT Academic Publishing Gmbh \& Co. KG, 2012. 700 p.

4. Varlamov O.O. (1997), "Algorithm of network cut on the nodes and arcs of its graph of complexity $\mathrm{O}(\mathrm{n} 2)$ " ["Algoritm razreza seti po vershinam i rebram ee grafa slozhnosti O(n2)"], Proceedings of NIIR. Moscow, pp. 92-97.

5. Chuvikov D.A. (2015), Development of electronic learning resource (ELR) "MIVAR". "MIVAR" - logical artificial intelligence, Saarbrucken, Germany: LAP LAMBERT Academic Publishing Gmbh \& Co. KG, 2012. 65 p.

6. Zhdanovich E.A., Chernychev K.A., Yufimychev K.A., Eliseev D.V., Chuvikov D.A. (2015), "Random algorithms calculation of service robot functioning on the basis of mivar approach" ["Vychislenie proizvol'nyh algoritmov funkcionirovaniya servisnyh robotov na osnove mivarnogo podhoda"], Radio industry, No. 3, pp. 226-242.

7. Varlamov O.O., Chuvikov D.A. (2015), The use of mivar-based approach for solving problems related to simulation modelling, Seventh 
All-Russia scientific-practical conference "Simulation modelling. Theory and Practice "(IMMOD 2015) Proceedings of the conference: In 2 vol. Trapeznikov's Institute of Control Sciences of Russian Academy of Sciences, Edited by Vasilyev, S.N., Yusupova, R.M., Moscow, pp. 280-284.

8. Chuvikov D.A. (2015), "Procedural animation application in solving intelligent tasks and problems related to situational three-dimensional modelling" ["Primenenie procedurnoj animacii v reshenii intellektual'nyh zadach i problem, svyazannyh s situacionnym trekhmernym modelirovaniem"], Radio industry, No. 3, pp. 184-190.

9. Chuvikov D.A. (2015), "Physics engine application in solving tasks related to situational three-dimensional modelling" ["Primenenie fizicheskogo dvizhka v reshenii zadach, svyazannyh s situacionnym trekhmernym modelirovaniem v real'nom vremeni'”], Radio industry, No. 3, pp. 191-199.

10. Chuvikov D.A. (2015), "Graphics engine application in solving intelligent tasks related to situational three-dimensional modelling" ["Primenenie graficheskogo dvizhka v reshenii intellektual'nyh zadach, svyazannyh s situacionnym trekhmernym modelirovaniem"], Radio industry, No. 3, pp. 200-209. Tewtet

11. Varlamov O.O. The review of twenty-five-year development of mivar approach to designing intelligent systems and artificial intelligence. Proceedings of NIIR. 2011, No. 1, pp. 34-44.

12. Varlamov O.O. The fundamentals of multi-dimensional information developing (mivar) space of data and rule representation. 2003. Information technologies, No. 5, pp. 42-47.

13. Varlamov O.O. Parallel information flow processing on the basis of virtual database flows. Proceedings of Universities. Electronics. 2003, No. 5, pp. 82-89.

14. Varlamov O.O. (2002), "Development of adaptive mechanism of logical inference on evolutionary interactive network of hyper-rules with multi-activators managed by data flow" ["Razrabotka adaptivnogo 
mekhanizma logicheskogo vyvoda na ehvolyucionnoj interaktivnoj seti giperpravil s mul'tiaktivizatorami, upravlyaemoj potokom dannyh"], Artificial intelligence, No. 3, pp. 363-370.

15. Varlamov, O.O. (2002), "Development of the linear matrix method of determining logical inference path on the adaptive network of rules" ["Razrabotka linejnogo matrichnogo metoda opredeleniya marshruta logicheskogo vyvoda na adaptivnoj seti pravil'], Proceedings of universities. Electronics, No. 6, pp. 43-51.

16. Varlamov O.O. Development of the method for paralleling multiple thread access to common database under conditions of prevention of mutual data corruption. Information technologies. 2003. No. 1, pp. 20-28.

17. Varlamov O.O. (2003), "System analysis and data model synthesis and information processing methods for developing on-line self-organizing diagnostic software suites" ["Sistemnyj analiz i sintez modelej dannyh i metody obrabotki informacii dlya sozdaniya samoorganizuyushchihsya kompleksov operativnoj diagnostiki"'], Artificial intelligence, No.3, 299 p.

18. Varlamov O.O. (2003), "System analysis and data model synthesis and information processing methods for developing on-line self-organizing diagnostic software suites" ["Sistemnyj analiz i sintez modelej dannyh i metody obrabotki informacii dlya sozdaniya samoorganizuyushchihsya kompleksov operativnoj diagnostiki"], Artificial intelligence, No.3, 299 p.

19. Varlamov O.O., Adamova L.E., Peterson A.O., Protopopova D.A., Skakunova E.A. (2014), "Research of approaches and major problems of natural Russian language understanding" ["Issledovanie podhodov i osnovnyh problem ponimaniya estestvennogo russkogo yazyka"], Automation and control in technical systems, No. 2, available at: auts. esrae.ru/10-196.

20. Varlamov O.O. (2005), "Development of intelligent systems on the basis of interaction between mivar-oriented information space and service oriented architecture" ["Sozdanie intellektual'nyh sistem na 
osnove vzaimodejstviya mivarnogo informacionnogo prostranstva i servisno-orientirovannoj arhitektury"'], Artificial intelligence, No.3, pp. $13-17$.

21. Varlamov O.O. (2007), "Development of active reflection theory as generalization of artificial intelligence theory and possibility of its implementation in mivar-oriented information space" ["Sozdanie teorii aktivnogo otrazheniya kak obobshcheniya teorii iskusstvennogo intellekta i vozmozhnost' ee realizacii v mivarnom infoprostranstve"], Artificial intelligence, No. 3, pp. 17-24.

22. Varlamov O.O. (2007), "Evolutionary databases and knowledge bases. Mivar-oriented information space" ["Evolyucionnye bazy dannyh i znanij. Mivarnoe informacionnoe prostranstvo"], Proceedings of Southern Federal University. Technical sciences, No. 2 (77), pp. 77-81.

23. Varlamov O.O., Adamova L.E., Eliseev D.V., Mayboroda Yu.I., Antonov P.D., Sergushin G.S., Chibirova M.O. (2013), "Comprehensive modeling of processes of text meaning understanding, speech and image understanding by computers on the basis of mivar-based technologies" ["Kompleksnoe modelirovanie processov ponimaniya komp'yuterami smysla tekstov, rechi i obrazov na osnove mivarnyh tekhnologij"], Artificial intelligence, No. 4, pp. 15-27.

24. Varlamov O.O., Vladimirov A.N., Badalov A.U., Chvanin O.N. Development of mivar method for logical and computational information processing for Automated Control Systems, simulators, expert real-time systems and architectures oriented to services. Proceedings of Radio Research and Development Institute. 2010. № 3, pp. 18-26.

25. Vladimirov A.N., Varlamov O.O., Nosov A.V., Potapova T.S. (2009), "Application of multiprocessor computational cluster of NIIR to parallel algorithms in scientific-technical and computational tasks" ["Primenenie mnogoprocessornogo vychislitel'nogo klastera NIIR dlya rasparallelivaniya algoritmov v nauchno-tekhnicheskih i vychislitel'nyh zadachah"], Proceedings of Radio Research and Development Institute, No. 3, pp. 120-123. 
26. Varlamov O.O., Vladimirov A.N., Nosov A.V., Potapova T.S. (2010), "The UDAV software: practical implementation of active trained logical inference with the linear computational complexity on the basis of mivar network of rules" ["Programmnyj kompleks «UDAV»: prakticheskaya realizaciya aktivnogo obuchaemogo logicheskogo vyvoda s linejnoj vychislitel'noj slozhnost'yu na osnove mivarnoj seti pravil'], Proceedings of Radio Research and Development Institute, Vol.1, pp. 108-116.

27. Varlamov O.O., Sergushin G.S., Adamova L.E., Eliseev D.V., Mayboroda Yu.I., Antonov P.D., Chibirova M.O. Mivar-based approach to modelling processes of text meaning understanding, speech and image understanding by computers. Automation and control in technical systems. 2013. №2(4), available at: auts.esrae.ru/4-80.

28. Mayboroda Yu.I., Sintsov M.Yu., Ozerin A.Yu., Kuzin A.A., Varlamov O.O. Automatic image tagging system on the basis of mivar technologies. Software systems: theory and applications. 2014, № 4, pp. 159-170.

29. Chuvikov, D.A., Kazakova, N.A., Varlamov, O.O., Hadiev, A.M. (2014), "Analysis of technologies of three-dimensional modelling and $3 \mathrm{~d}$ object development for different intelligent systems ["Analiz tekhnologij trekhmernogo modelirovaniya i sozdaniya $3 \mathrm{~d}$ ob"ektov dlya razlichnyh intellektual'nyh system"'], Automation and control in technical systems, No. 2.1, pp. 84-97.

30. Varlamov O.O., Mayboroda Yu.I., Sergushin G.S., Hadiev A.M. (2015), "Application of mivar expert systems to solving tasks of text understanding and image recognition" ["Primenenie mivarnyh ehkspertnyh sistem dlya resheniya zadach ponimaniya teksta i raspoznavaniya izobrazhenij"], In the world of scientific discoveries, No. 6 (66), pp. 205-214.

\section{DATA ABOUT THE AUTHORS}

Panferov Alexey Andreevich, Postgraduate Student, Department of "Special machinery" Bauman Moscow State Technical University 
5, 2 Baumanskaya Str., 5, Moscow, 105005, Russian Federation a.panferov@mivar.ru

Zhdanovich Elizaveta Alexandrovna, Software Engineer

Scientific-Research Institute "MIVAR" (SRI “MIVAR”)

72, Oktyabrskaya Str., Moscow, 127521, Russian Federation e.zhdanovich@mivar.ru

Yufimychev Konstantin Anatolevich, Chief Development Officer

Scientific-Research Institute "MIVAR" (SRI "MIVAR”)

72, Oktyabrskaya Str., Moscow, 127521, Russian Federation k.yufimychev@mivar.ru

Chuvikov Dmitry Alekseevich, Postgraduate Student, Department of «Automated Control Systems»

State Technical University - MADI

64, Leningradsky prospekt, Moscow, 125319, Russian Federation d.chuvikov@mivar.ru 